\title{
O BECO DOS ARTISTAS E O ESTIGMA: INSTERSECÇÕES DE GÊNERO, SEXUALIDADE, RAÇA E CLASSE SOCIAL
}

\author{
Andressa Ribeiro ${ }^{1}$
}

\section{Introdução}

Este artigo é fruto de uma etnografia, realizada durante dois anos sobre um espaço de sociabilidade homossexual, em Salvador-Bahia, cujo nome é Beco dos Artistas. O Beco dos Artistas se localiza no bairro Garcia, na Av. Cerqueira Lima e é uma viela, literalmente um beco, constituída por quatro bares: o Bar de Eduardo, o Green Bar, o Camarim e o Bar Cultural. Essa viela não tem muita visibilidade e muitas pessoas que passam pela avenida principal não percebem este espaço. Atualmente, o Beco dos Artistas funciona de terça a domingo, durante a noite.

Inicialmente, o Beco dos Artistas era frequentado pela classe artística e intelectual de Salvador. Grandes nomes do teatro e da música popular brasileira frequentaram o lugar como, por exemplo, Caetano Veloso, Gilberto Gil, Lulu Santos, Maria Bethânea e Zizi Possi. Por se localizar próximo aos principais teatros de Salvador e a Escola de Teatro e de Belas Artes da Universidade Federal da Bahia, o Beco passou a ser o ponto de encontro tanto de intelectuais quanto de artistas. Essa experiência marcou de tal modo o lugar que este recebeu a denominação de Beco dos Artistas. Este período foi considerado o período áureo do Beco.

No entanto, com o passar dos anos e por motivos que não contemplarei nesse artigo, o Beco deixa de ser um reduto da classe artística e transforma-se em um espaço de sociabilidade homossexual, mais especificamente um gueto gay, frequentado majoritariamente por pessoas negras, provenientes da periferia de Salvador e de baixo poder aquisitivo. Simultaneamente a essa transformação - de um lugar dos artistas para um gueto gay - o beco passa a concentrar um forte estigma e torna-se, ao mesmo tempo, um lugar marginalizado com fronteiras claras. Essa transformação do lugar é marcada pelo termo que os freqüentadores cunharam para se referir ao beco, esse termo é BA, que quer dizer Baixo Astral. O beco deixa de ser dos artistas com as mesmas iniciais do termo anterior adquire outro sentido, qual seja este, um lugar baixo astral.

\footnotetext{
${ }^{1}$ Universidade Federal da Bahia, Brasil.
} 
O Beco dos Artistas, atualmente, se divide em dois espaços: o espaço dentro dos bares e o espaço da rua. É o espaço da rua que concentra os fatores mais fortes para a sua estigmatização. A pretensão desse artigo consiste em entender o que permeia a estigmatização do lugar; pretendo refletir sobre o próprio sentido da estigmatização. Para isso descreverei as práticas, grupos e comportamentos que se dão no espaço da rua, refletindo como essas práticas e comportamentos contribuem para uma avaliação negativa do lugar, assim como, tentarei compreender de que modo a intersecção de fatores como a cor da pele, a classe social, o gênero e a sexualidade fortalece essa estigmatização.

\section{O espaço da rua}

A rua é um ponto de encontro para muitos frequentadores e é, também, o espaço que as pessoas utilizam para namorar, se abraçar e se beijar de forma mais livre. Como alguns frequentadores chamam "é o espaço da pegação". A rua é um espaço de sociabilidade distinto de dentro dos bares. As pessoas que ficam na rua, segundo alguns entrevistados, ou não têm dinheiro para consumir, ou estão em clima de flerte. Um entrevistado diz:

\footnotetext{
A - Não gosto muito das pessoas que ficam na rua. Tenho a impressão que são do tipo de pessoa que não podem sentar em um bar e pedir uma cerveja e aí utilizam o espaço da rua para ficar e conseguir as coisas de uma forma que não considero muito legal.

E-Como assim?

A - Tem muita coisa desagradável que acontece aí na rua. Tem pessoas que se aproveitam de outras, na tentativa de conseguir dinheiro ou de conseguir uma cerveja. Enganam, mentem e até coisa pior.
}

A rua é um espaço de exposição, onde as pessoas circulam com o intuito de trocar olhares, paquerar, com a expectativa de conhecer alguém, arranjar um(a) parceiro(a) sexual. É quase uma passarela, as pessoas desfilam para mostrar o que têm de melhor. $\mathrm{O}$ olhar é a principal estratégia de flerte. Só a segurança de um olhar retribuído permite a continuidade do flerte. O olhar é a primeira instância de contato e troca entre duas pessoas que se interessam mutuamente. Por outro lado, o olhar não correspondido é um sinal de que não existe uma reciprocidade entre pares e, na maioria das vezes, leva a um cessar da tentativa de aproximação. Isso é muito comum no Beco, onde as buscas 
afetivo-sexuais são, em sua maioria, pautadas na objetividade e no imediatismo. Simmel (1939) descreve muito bem esse poder do olhar e o olhar como um tipo de laço sociológico:

\begin{abstract}
Descendo agora para os órgãos sensoriais, os olhos desempenham uma função sociológica particular: o enlace e ação recíproca dos indivíduos que se miram mutuamente. Acaso seja esta a relação mútua mais imediata e mais pura que existe. Todos os outros segmentos sociológicos costumam ter um conteúdo objetivo e gerar um objetivo. Até mesmo a palavra falada e ouvida tem uma significação objetiva que poderia comunicar-se de outro modo. Mas a vivíssima ação recíproca em que entram os homens ao mirar-se cara a cara, não se cristaliza em produtos objetivos de nenhum gênero; a unidade que se cria entre eles permanece toda no processo mesmo, subsumida a função. E esta relação é tão forte e sutil que só se verifica pelo caminho mais curto, pela linha reta que vai de olhos a olhos. O desvio mais mínimo, o mais ligeiro distanciamento da mirada destrói por completo a peculiaridade do laço que cria (Simmel, 1939: 238).
\end{abstract}

A rua é o espaço onde o olhar é um marcador. As pessoas se olham, observam umas às outras, observam a roupa, o comportamento, o corpo. $\mathrm{O}$ fato de a rua ser um espaço já legitimado como um local de flerte, de algum modo, explica essa força que o olhar tem na sociabilidade que se dá no espaço da rua. No entanto, penso que o olhar na rua não se resume à busca afetivo-sexual, mas está também relacionado a um desejo de sociabilidade mais amplo, no desejo de ver pessoas, sociabilizar e interagir. Também existe no Beco, principalmente no espaço da rua, o que Lacombe (2009) chama de modo indireto de aproximação, ou o que eu chamaria de olhar indireto. Tal categoria surge em um trabalho etnográfico que Lacombe (2009) faz em duas boates de sociabilidade lésbica da periferia do Rio de Janeiro. Ela diz;

Este modo indireto de aproximação tem outra variante, desta vez fixada no intercâmbio de olhares e não na troca verbal: uma pessoa que não faz parte de determinado grupo, cruza o olhar com outra que pertence a ele, mas, que não é aquela de seu interesse; explicita então, sempre através da troca de olhares ou de gestos, o gosto por determinad@ integrante do grupo, de tal modo que o interlocutor informe a situação para ela, deixando a palavra final no cruzamento de olhares entre @s interessad@s. Se for aceita, a pessoa aproxima-se do grupo, ou @ integrante sai do seu grupo e vai até a outra, começando o flerte. Entretanto, a rejeição se explica com o afastamento do olhar de todo o grupo, indicando assim a imposição da exclusão (Lacombe, 2009: 386).

Por mais que Lacombe (2009) esteja se referindo aqui a formas de interação lésbica, percebo que, no Beco, esse mesmo tipo de comportamento acontece em relação aos homens. Esse "olhar indireto" quando não correspondido pela pessoa que é alvo do 
interesse, muitas vezes, acaba por proporcionar uma interação entre o interessado e o grupo da pessoa de interesse, criando laços de sociabilidade que, embora iniciados por um interesse afetivo-sexual, não se restringiram a tal interesse. Amizades se formam daí, assim como conversas e trocas.

\section{Os grupos}

Percebe-se a existência de diferentes grupos na rua. Existem os estudantes, meninos e meninas que chegam lá com a farda do colégio e levam seu vinho São Jorge ${ }^{2}$, pirulito na boca, postura de "vamos invadir o pedaço". Muitos deles não são homossexuais, aproveitam o espaço para beber, gritar e fazer barulho. Como é um lugar que não cobra entrada e que possui um nível alto de permissividade, então, se tornou um bom ponto de encontro para esses estudantes. Geralmente, são jovens de 16, 17, e 18 anos, jovens de menor poder aquisitivo, vindos de colégios públicos. Além do grupo dos estudantes, há as pessoas que possuem uma aparência mais hippie. Esse grupo geralmente anda com violão debaixo do braço, com uma garrafa de São Jorge e nunca entram nos bares. Senta no final do Beco, próximo da casa dos moradores, para tocar violão e conversar. Esses são os dois grupos mais destoantes do espaço, já que a maioria das pessoas que estão ali se identifica como homossexuais e eles não. Eles vão ali para viver a rua. O Beco, para eles, é a rua. A rua é o único espaço que lhes é acessível e que lhes interessa.

Se, por um lado, posso denominar os dois grupos citados acima, devido ao fato desses grupos destoarem da totalidade do Beco e já que eles compartilham características próprias que os distinguem enquanto grupo, não posso fazer o mesmo classificar os indivíduos - tendo como parâmetro os atributos de gênero. Isso porque, o que eu observei em campo foi muito mais uma mistura de indivíduos que manejavam de forma diferente os atributos de gênero do que, de fato, grupos com fronteiras bem delimitadas. Assim, empacotar esses indivíduos em grupos como “@s mais masculin@s" ou "@s mais femin@s" seria muito mais uma consequência da minha reflexão e da necessidade de categorizar, própria do pensamento, do que, de fato, uma realidade percebida em campo. Falarei, por isso, em termos de indivíduos que se misturam dentro do Beco e não de grupos.

${ }^{2} \mathrm{O}$ vinho São Jorge é um vinho bem barato e de má qualidade. 
Além disso, percebo que existe uma tendência nas etnografias atuais feitas em contextos de sociabilidade LGBT no Brasil, em dividir os homossexuais, tanto homens quanto mulheres, em “@s mais masculino@s" e “@s mais feminin@s”. Fico me questionando, até que ponto, essas categorizações e divisões não retificam a dicotomia auto-excludente entre o feminino e o masculino e, ao mesmo tempo, criam subespécies dentro de um grupo - os homossexuais - que já é visto como uma espécie à parte (Foucault, 2007). Ao fazê-lo, além de criar essas subespécies, a meu ver, fortalecem a própria ideia do homossexual como uma espécie à parte.

Ainda que, por vezes, seja necessário utilizar essas categorizações de 'mais masculin@s' ou 'mais feminin@s', gostaria de frisar que esses atributos de gênero não são fixos e coerentes, mas se espalham pelas pessoas e subjetividades de formas distintas. "A univocidade do sexo, a coerência interna do gênero e a estrutura binária para o sexo e o gênero são sempre consideradas como ficções reguladoras que consolidam e naturalizam regimes de poder convergentes de opressão masculina e heterossexista" (Butler, 2008: 59).

Nesse sentido, os atributos de feminilidade e masculinidade se distribuem por entre os indivíduos como um espectro que ora aparece com mais força em um indivíduo, ora com menos força em outro. Existem homens homossexuais que são mais "femininos", usam calças coladas, fazem a sobrancelha, usam muitos colares, alguns usam brincos e passam gloss na boca. Geralmente, são homossexuais de menor poder aquisitivo. Isso é perceptível pelo tipo de roupa que usam como, por exemplo, o aspecto da calça jeans e o aspecto da blusa. Alguns escovam o cabelo, estes são em sua maioria negros. O Beco é formado, em sua maioria, por esse tipo de público. Mas, mesmo entre esses indivíduos que usufruem do atributo da feminilidade de forma mais enfática, existem diferenças e gradações no uso da feminilidade. Por outro lado, existem homens homossexuais que se vestem e se comportam de uma forma mais "masculina". Usam tênis, calça mais solta e folgada, blusas folgadas. Não percebi uma distinção de classe nos homens que se vestem assim. Eles - os homens que se vestem e se comportam de forma mais "masculina"- são tanto homens de classe menos abastada quanto homens de classe média, tanto negros quanto brancos, já os gays que se vestem de forma mais afeminada são, a maioria, de aparência mais pobre, de pessoas que possuem um baixo poder aquisitivo. Percebe-se, então, que a forma de manejar o gênero está ligada a outras posições do sujeito, como classe e cor de pele. 
Facchini (2009), ao falar de mulheres lésbicas, afirma que o fato de muitas mulheres rejeitarem a postura masculina e optarem por uma postura mais feminina e discreta tem uma relação muito íntima com a classe social dessas mulheres e em como elas manejam o estigma relacionado à homossexualidade. Geralmente, essas mulheres vêm de classes sociais mais altas, onde existe uma alta vigilância em termos de gênero, não só da família, mas, do seu ambiente social como um todo e, ao mesmo tempo, são mulheres que estão em "relações sociais caracterizadas menos pelo rompimento do que pelo desejo de aceitação e manutenção da convivência" (Facchini, 2009: 328). Embora essa reflexão de Facchini (2009) se refira a mulheres, acredito que, também, possa se estender aos homens, já que, também, entre os homens, como percebi no Beco, existe uma relação entre classe social e masculinidade/feminilidade. $O$ manejo da masculinidade/feminilidade pode ser também uma forma de manejar o estigma. "A revelação da identidade sexual ou das preferências eróticas através da aparência é algo que se pode - e deve - manejar a fim de evitar situações de conflito e preconceito" (Facchini, 2009: 325)

As mulheres, em sua maioria, têm uma aparência mais masculina, manejam essa masculinidade com adereços como calças folgadas, boné para trás, calcinha aparecendo, blusa regata folgada e um top à mostra por dentro. Mas, também, existem as mulheres que manipulam adereços considerados mais femininos, como calça colada, salto alto, brincos, batom, maquiagem, cabelo alisado, blusa decotada. Já presenciei no Beco tanto mulheres que manipulam mais a postura corporal e os adereços ligados a uma posição feminina e as que manipulam atributos mais ligados ao ideal de masculinidade. Muitas de essas mulheres que se utilizam mais dos atributos relacionados à masculinidade são mal vistas pelos próprios frequentadores do Beco e por alguns donos de bares e são consideradas umas das responsáveis pelo estigma que recai sobre o Beco. São, muitas vezes, consideradas arruaceiras, sem educação e causadoras de problemas. A partir de entrevista feita com mulheres lésbicas, Facchini (2009) diz:

Entre a maior parte das entrevistadas, as masculinizadas são quase sempre citadas como 'outras' relativamente distantes, sendo criticadas por tornarem socialmente visíveis suas preferências eróticas, de um modo que poderia se tornar perigoso, e acusadas de procurar chocar ou agredir com sua aparência, o que poderia depor contra a imagem de todas as mulheres que gostam de mulheres (Facchini, 2009: 322). 
Essa visão negativa que recai sobre as mulheres "mais masculinizadas" pode ser uma consequência da pretendida e pressuposta continuidade entre o sexo e o gênero, como bem explica a autora Judith Butler (2008) em seu livro "Problemas de Gênero". Quando Facchini (2009) diz que essas mulheres mais masculinizadas são acusadas de chocar ou agredir com sua aparência, é preciso pensar também, por que tal aparência se apresenta como chocante ou agressiva e em quais contextos de significados elas os são. Assim, assumir que tais posturas são agressivas é também assumir que existe um contexto de significados, em termos de gênero e sexo, que as coloca nessa posição. "Um conjunto decididamente heterogêneo que engloba discursos, instituições, organizações arquitetônicas, decisões regulamentares, leis, medidas administrativas, enunciados científicos, proposições filosóficas, morais" (Foucault, 1985: 244) que conformam o que Foucault (2007) chama de dispositivo da sexualidade. É esse dispositivo de controle e produção, a serviço sempre de um tipo de parentesco tido como heterossexual (Butler, 2003) que coloca tanto os homens como as mulheres, que não correspondem à coerência pressuposta e exigida entre sexo/gênero/desejo/prática sexual (Butler, 2008), em uma posição de marginalidade e, por conseguinte, capaz de chocar e agredir ${ }^{3}$.

Em termos de pares, já presenciei "mulheres mais femininas" com outras "mulheres femininas", outras "mais masculinas" com "femininas" e, também, com "masculinas". Ao perguntar a uma garota sobre qual sua preferência, ela respondeu que nenhuma, desde que fosse mulher; já outras apresentavam preferências, mas essas posições eram muito variadas. Entre os homens, também, já presenciei o flerte com as combinações de gêneros mais distintas entre pares. Embora, ao conversar tanto com homens quanto com mulheres, alguns deles apresentassem preferências, tais preferências não são suficientes para estabelecer categorias em termos de relações, já que elas são muito variáveis de indivíduo para indivíduo e, muitas vezes, independem da postura mais masculina ou feminina que sustentam.

Vez ou outra, no decorrer do ano, aparecem estrangeiros que são muito disputados pelos frequentadores mais assíduos, principalmente, pelos garotos que fazem programas, ou garotos que se aproximam para conseguir tomar uma cerveja e fumar um cigarro.

\footnotetext{
${ }^{3}$ É fato que, dentro do Beco, o incômodo que existe em relação às mulheres mais masculinizadas tem relação com um tipo de comportamento dessas mulheres que está para além da performance de gênero. Isso, no entanto, não faz com que essa "incoerência" entre sexo e gênero não seja um dos fatores relevantes para essa opinião negativa em relação a tais mulheres.
} 


\section{O estigma}

A rua é o espaço que concentra maior parte dos fatores que contribuem para a sua estigmatização. É na rua que se dá o uso de substâncias psicoativas. As pessoas vão para o fundo do Beco para usar maconha. Utilizam um orelhão que não funciona mais, também no fundo do Beco, para cheirar cocaína. Já presenciei, em horários de pouco movimento, pessoas fumando craque na janela dos bares. No período de campo, presenciei, inclusive, cocaína sendo apreendida por um policial civil.

Além das drogas é na rua que se desenvolve uma trama de trocas sexuais. Muitos garotos que se aproximam dos clientes com aparência mais abastada e se utilizam da sedução para conseguir tomar uma cerveja. Os pequenos furtos também acontecem na rua. Esses furtos são atribuídos aos garotos de 15, 16, 17 anos que são heterossexuais e vão para o Beco roubar, geralmente roubam celular e dinheiro. Percebi, também, a existência de michês na rua.

Para Néstor Perlongher (1987), "o michê é uma espécie sui generis de cultores da prostituição: varões geralmente jovens que se prostituem sem abdicar dos protótipos gestuais e discursivos da masculinidade em sua apresentação perante o cliente" (Perlongher, 1987: 17). Nestor Perlongher (1987), em seu estudo sobre michês no centro de São Paulo, aponta para a venda e prostituição de um valor que é muito caro à nossa sociedade, qual seja este, a masculinidade. Perlongher (1987) diz que, se o cliente do michê fosse uma mulher, provavelmente, ela continuaria a ser chamada de puta, já que nosso referencial de prostituição não é tanto o corpo vendido, mas o corpo penetrado. Assim, o michê inverte essa lógica, na medida em que o que ele está vendendo não é o corpo penetrado, mas, a própria masculinidade, valor supostamente supremo e inalienável. "A prática da prostituição viril obriga a desfazer a costumeira associação entre a venda de favores corporais e a feminilidade" (Perlongher, 1987: 20).

Para Perlongher (1987), os michês, em sua maioria, encaram sua prática como provisória e descarregam o estigma sobre o parceiro, isso porque o fato de eles não saírem da economia discursiva e gestual de normalidade, ligada à coerência pressuposta entre sexo e gênero, lhes permite tal posição. Isso configura um "curioso comércio onde os 'normais' aparecem prostituindo-se para os 'desviantes'” (Perlongher, 1987: 20). Geralmente essa relação se dá sob três eixos básicos: "um eixo de gênero (mais masculino/menos masculino), um eixo de idade (mais jovem/ menos jovem) e um eixo 
de classe (mais abastado/menos abastado)" (Perlongher, 1987: 42). Essas são algumas características da relação de troca que se dá entre os michês e seus clientes.

No período de campo, tive a oportunidade de dialogar com dois michês. Ao chegar em casa, tentei reproduzir a conversa que tive com eles. Colocarei um trecho do diário de campo referente a uma conversa que tive com um deles, pois penso ser bastante ilustrativo:

Nesse meio tempo que fiquei observando as pessoas, um rapaz sentou do meu lado na mesa. Esse rapaz fazia parte do grupo de aparência mais despojada, tinha uma aparência bem masculina, o olhar sério, uma postura fechada; estava vestido com uma bermuda cujo lado direito era preto e o lado esquerdo era branco, uma blusa branca, um tênis um pouco velho e de cor branca e um boné para trás ${ }^{4}$. Quando ele se sentou, ficou bem calado e, então, resolvi puxar conversa com ele. Perguntei se ele vinha sempre aqui no Beco e ele disse que não, de vez em quando, ele respondeu. Começou a falar que estava ali esperando um amigo, que tinha marcado com ele desde 21:00h e ele ainda não tinha chegado. Já eram 23:15h. Falou que seu amigo estava querendo dar o troco, porque, outro dia, ele tinha marcado com esse amigo e não pôde aparecer. Mas ele não foi, segundo disse, porque realmente não pôde ir e não porque não queria ir ou qualquer coisa desse tipo. Perguntei se esse amigo era namorado dele e ele respondeu que não.

Ele: Não, não, pô. É só amigo mesmo, não curto isso não. A gente só vem para cá para gastar mesmo, beber uma cerveja, é só isso. E você está aqui sozinha?

Eu: Sim, estou.

Ele: Mas, eu vi você conversando com um rapaz.

Eu: Ah, é um amigo, mas já saiu. E esse amigo, você acha que ele vem ainda?

Ele: Não sei. Uma coisa que eu não gosto é isso, marcar e não aparecer, se marcou, tem que vir.

Eu: Você mora aonde?

Ele: Em Lauro de Freitas e você?

Eu: Eu moro aqui pelo Campo Grande mesmo.

Ele: E você? Curte a onda?

Eu: Como assim?

Ele: As menininhas?

Eu: Não, não curto.

Ele: Sei, sei, vai me dizer que não curte.

Eu: Não.

Ele: Eu também não curto não, só se rolar uma grana.

Eu: E, geralmente, rola por aqui?

Ele: Aqui de vez em quando rola.

Eu: E você cobra quanto?

Ele: 150 reais.

Eu: Para ficar quanto tempo?

Ele: Até gozar. Bom foi um coroa que eu peguei esses dias, foi só colocar a cabeça que ele gozou. Ah, se todos fossem assim, ia ser bom. E um deputado, José ${ }^{5}$, que me paga só para fazer companhia a ele. Eu viajo com ele, como, bebo e ainda ganho para fazer companhia a ele.

Eu: Mas você não faz nada?

\footnotetext{
${ }^{4}$ Em outros estudos sobre lugares de sociabilidade GLS também se encontra a referência ao boné para trás como uma espécie de signo dos garotos que se prostituem e que manejam o atributo da masculinidade para fazê-lo. Ver Simões (2008).

${ }^{5}$ Esse é um nome fictício. Os nomes relatados nessa história foram alterados por mim, para resguardar as pessoas envolvidas no relato.
} 
Ele: Nada, ele só quer minha companhia. Disse que sabe que eu não gosto de fazer essas coisas e por isso eu não preciso fazer.

Eu: Você acha que ele é apaixonado por você?

Ele: É sim, ele gosta de mim. Agora, o mal, é que ele cheira muito pó, eu não gosto. Se bem que um dia eu cheirei e fiquei doidão, o nariz escorrendo. Mas não é a minha, não. Prefiro um beck que você fica de boa e pronto.

Eu: Acho que tem um cara te olhando ali.

Ele: É! Ele está olhando já tem um tempo. Espera aí que eu vou ver qual é?

Ele se levantou, aproximou-se do cara, quando estava perto pegou no pênis, apertou, ajeitou até ficar mais volumoso e foi conversar com o cara que estava olhando para ele. Voltou e fez um sinal para mim como se não tivesse rolado nada. Depois se aproximou de mim e me chamou para sentar em outro lugar, no passeio do bar de Eduardo. Aceitei e fomos sentar lá. Ao sentarmos, percebi que tinha um rapaz que olhava muito para ele. Sentamos, mostrei esse rapaz e ele disse que já tinha percebido. Esse rapaz se aproximou, recostou num poste que ficava na nossa frente e continuou encarando.

Sem esperar, Rodrigo se levantou e foi até o Bar Camarim, chegou lá e começou a conversar com dois rapazes. Os olhos do rapaz que estava encostado no poste foram acompanhando o movimento de Rodrigo, e fez uma expressão de tristeza, ou frustração, não sei bem, quando viu que Rodrigo estava conversando com outros dois rapazes que pareciam ter uma condição financeira muito mais favorável para pagar pelo produto do que ele. Quando os rapazes não estavam olhando, Rodrigo olhava para mim e sinalizava, para explicar que não estava rolando a negociação. Depois ele se aproximou de mim novamente e disse:

Ele: Não rolou nada, eles não queriam pagar o preço.

Eu: Aquele rapaz do poste ainda está te olhando. Você acha que ali rola?

Ele: Só vendo.

E aí Rodrigo levantou e foi até lá falar com o rapaz, mas também não rolou. Depois ele voltou e se sentou novamente na cadeira ao meu lado e disse que não tinha rolado, pois o cara não tinha grana para pagar. Continuamos conversando e, depois de muito conversarmos, ele perguntou: e você, se uma mulher te oferecesse uma grana você aceitaria? Nesse momento, fiquei sem saber o que falar. Fiquei com receio de falar não e ele se sentir julgado. Também não queria falar que sim, que aceitaria, pois, sei que de fato é algo que eu não faria. Então, respondi: não sei. Achei interessante essa pergunta, pois me pareceu uma busca por aceitação. Depois de um tempo, a conversa se encerrou, me despedi dele e parti. (Diário de campo, 03/09/2008)

Ainda tive oportunidade de conversar com outro garoto de programa. Esse rapaz, no entanto, não fazia programa só com homens, mas, também, com mulheres. Ele se diz bissexual e pretende casar e constituir família. Segundo ele, mulher é bem melhor para ter um relacionamento estável. Ele falou que raramente sente tesão por homens e pelas mulheres com quem ele transa, mas que é uma coisa profissional. Para o homem ele sempre cobra, mas, para as mulheres, às vezes, ele não cobra, pois, segundo ele, é uma coisa mais natural, que faz parte mais da sua natureza. Para homem, quando ele está na posição de ativo, cobra 60,00 reais e para ser passivo 80,00 reais. Disse que, quando um homem procura um garoto de programa, ou ele é muito feio fisicamente ou velho e não consegue arranjar um rapaz de forma natural, ou ele é muito tímido e tem dificuldade 
em externar seu desejo homossexual para outro homem, então, paga um garoto para satisfazer momentaneamente esse desejo ${ }^{6}$.

Além disso, alguns espaços da rua, principalmente as extremidades, tornaram-se espaços onde o sexo e, quando não o sexo em vias de fato, comportamentos muito próximos disso são publicizados. Ouvi vários relatos de pessoas que presenciaram casais transando no fundo do Beco ou fazendo sexo oral. Essa permissividade em relação a comportamentos sexuais e uso do corpo não se dão apenas entre os homossexuais, mas, também, entre os poucos adolescentes heterossexuais que frequentam o Beco. Um trecho do relato de campo é bem interessante nesse sentido:

Eram três garotas, provavelmente de áreas periféricas de Salvador, baixas, gordas, negras, com shorts bem curtos, barriga de fora, que não pareciam ser lésbicas, mas, pareciam estar ali só se divertindo. Estava tocando pagode e elas dançavam, rebolavam até o chão com expressões bem sensuais. Além delas, estava outra garota negra, magra, cabelo escovado, com blusa e short que cobriam mais seu corpo. Essa garota colocou a mão no poste, empinou a bunda e veio um rapaz por traz dela que ficou roçando a genitália na sua bunda. Enquanto ela descia e subia a bunda, esfregando-a na genitália dele, ele passava a língua pelos lábios, dava uns tapas na bunda dela e ela fazia uma expressão de quem estava gostando muito. Além disso, havia uns rapazes que se aproximaram das três garotas. Um deles, o mais gordo, de boné e óculos, que parecia ser o que tinha os atributos físicos mais desvalorizados em relação aos padrões sociais de beleza e corpo, foi para trás de uma dessas três garotas, a pegou pela cintura, ela se inclinou, descia e subia, enquanto ele rebolava roçando o pênis na bunda dela. (Diário de campo, 16/10/2009)

Tudo isso gerou o que eu chamo da 'ética do tudo pode'. Segundo alguns frequentadores, donos de bares e moradores, o Beco é o lugar onde tudo pode acontecer, um lugar de permissividade:

Tudo ali se pode, tudo, tudo pode acontecer naquele lugar, até você transar no fundo do Beco acontece e, muitas vezes, já aconteceu de eu ver e de quase estar lá culminando o ato sexual, sabe? Eu mesmo falando isso agora, eu mostrei que pode sim, você pode fazer tudo lá dentro, e, hoje em dia, eu não vejo mais assim, eu vejo que você pode fazer tudo, você pode fazer tudo lá dentro. (Informação verbal)

Fico me questionando se o fato do Beco dos Artistas ter se tornado um espaço GLS, ter assumido essa bandeira e pelo fato de a prática homossexual, ainda ser, nos dias de hoje uma prática marginalizada - se pode a homossexualidade, tudo pode - não

\footnotetext{
${ }^{6}$ Não ouvi falar de programas entre mulheres dentro do Beco, no entanto, ao conversar com uma frequentadora em campo, ela disse que no seu bairro, um bairro periférico em Salvador, por ela ser uma pessoa que paga sempre o que bebe, que não pega fiado, então, umas garotas do bairro se aproximam, sentam no colo dela, para que ela pague uma cerveja ou um cigarro. A frequentadora disse que percebe essa situação e não gosta muito, pois percebe que é uma aproximação movida pelo interesse no seu dinheiro.
} 
levaria as pessoas a pensarem que, por isso, aquele espaço também possibilitaria a existência de outros comportamentos que, também, são marginalizados, mas, que naquele espaço poderiam ser praticados. É o caso, por exemplo, do uso de cocaína e maconha na rua, dos furtos, da presença de michês. Perlongher (1987) toca nesse ponto, em seu estudo sobre o gueto gay no centro de São Paulo, no fato de como determinados espaços homossexuais convivem com outros códigos marginais.

[...] a massa de gays que circula pelo centro da cidade, num circuito estável e difuso, está em relações fatuais de contigüidade com as demais marginálias que instalam, no espaço urbano deteriorado, suas banquinhas: prostitutas, travestis, michês, malandros e todo tipo de lúmpens (Perlongher, 1987: 26).

Numa conversa que tive com uma frequentadora do Beco, também se fala dessa relação de proximidade que uma posição de marginalidade, por vezes, pode proporcionar em relação a outras posições marginais.

Quando você já transgride uma norma, quando você já não é tão 'normal' assim, fica mais fácil você transgredir outras normas. Se você já está na merda, fica mais fácil se afundar nela. É diferente de uma mulher que vai casar e ter filhos, constituir família. (Informação verbal)

Essa proximidade de posições marginais faz com que, de certo modo, os indivíduos que ocupam essas posições, no tecido social, acabem ocupando também espaços físicos semelhantes, é o que Perlongher (1987) chama de "territórios marginais". Assim, o Beco, além de ser um espaço frequentado por homossexuais, acabou por se tornar um ponto que concentra outras atividades marginais. Percebe-se que, na medida em que a prática homossexual foi-se tornando mais explícita no Beco, outras atividades como o uso e venda de substâncias psicoativas ${ }^{7}$, passaram a incidir, também, de forma mais explícita. O fato de o Beco ser um espaço de sociabilidade homossexual deixa margem, ou possibilita uma maior permissividade e uma maior abertura em direção a outras práticas que, também e ainda, ocupam uma posição

\footnotetext{
${ }^{7}$ É fato que o uso de substâncias psicoativas como o craque vem crescendo em Salvador de um modo geral, no entanto, esse crescimento e esse uso não são constatados em qualquer espaço. Percebo uma postura de alguns jovens que, muitas vezes, não são nem frequentadores e que usam essas substâncias no Beco do tipo - ah, aqui a gente pode. Essa postura mantém uma relação com a percepção que esses jovens têm sobre o lugar, e essa percepção, claro, passa pelo fato de o Beco ser um espaço de sociabilidade GLS, onde, de um modo ou de outro, alguns padrões normativos já são rompidos.
} 
marginal na nossa sociedade. Isso acaba se refletindo no próprio espaço físico e o Beco se torna representativo dessa marginalização social e simbólica.

Outro fator de descontentamento, principalmente por alguns donos de bares, é o tipo de comportamento de alguns frequentadores. A fala de Estela, dona do Green Bar e de Marcelo, responsável pelo Bar Cultural é bem interessante nesse sentido:

\begin{abstract}
Por que elas acham que aqui é o lugar delas, aqui é o meio, cem por cento, quase gay, entendeu? Então, elas acham que podem fazer isso e eu não consigo entender por quê. Eu sempre pergunto as pessoas que eu conheço, se vocês querem respeito, querem ser respeitados pela sociedade, querem que a gente olhe para vocês como pessoas, entre aspas, normais, então, por que vocês são tão anormais (grifo nosso), fazem coisas tão esdrúxulas, tão loucas, que faz com que a gente olhe para vocês realmente com olhos (gaguejou), que a gente olhe para eles com olhos negativos e aí rotulá-los no caso de pessoas mal educadas, pessoas que gostam de se mostrar, que gostam de dizer eu posso. Eles acham que são, assim, mais sabidos que a gente, como, por exemplo, entrar no banheiro duas pessoas e fingir que só tem uma, entendeu? É difícil entender como as pessoas querem tanto se colocar na sociedade e agir assim com a sociedade, porque, se nós tivéssemos alguma coisa contra eles, eu e meu marido que somos heterossexuais, a gente não estaria aqui, nem atendendo, nem beijando, abraçando alguns. Porque, a gente tem essa intimidade, se a gente tivesse algum nojo, algum medo, algum receio, a gente não estaria aqui e eles não entendem não, eles acham que tudo pode e pronto. (Estela, informação verbal)
\end{abstract}

A fala de Marcelo também é ilustrativa:

\begin{abstract}
Não há necessidade de você agir assim publicamente: você entrar no banheiro e fazer sexo dentro do banheiro, você sentar e querer cheirar pó em cima da mesa, andar na rua e querer fumar, cheirar pó na rua, ou fazer até sexo na rua. Tem pessoas que não sabem se dar ao respeito, no momento certo, na hora certa para fazer o que ele quer. Naquele momento, ele não está se dando ao respeito. Tem que se dar o respeito. Até porque, no meu estabelecimento aqui, se chegar um casal de hetero e entrar no banheiro junto, eu vou mandar sair. Se agarrar demais em um canto e eu perceber que quer fazer orgia, eu mando sair, eu mando parar. Então, não é porque é homossexual ou não. É porque você tem que se dar o respeito, independente de ser homem, mulher, homossexual, bi, hetero, não interessa. As pessoas têm que saber respeitar o espaço, o próprio espaço. Porque, quem não respeita seu próprio espaço, a sociedade não vai aceitar nunca. Como é que vou conseguir fazer com que a sociedade respeite meu espaço se eu faço orgia dentro dele? Então, não pode ser isso. Dizem: hoje as pessoas têm que abrir a mente. O homossexual é que tem que abrir a mente da sociedade, não só a sociedade abrir a mente para ele.
\end{abstract}

Percebe-se que, nas duas falas, tanto na fala de Estela quanto na fala de Marcelo, o mau comportamento dos frequentadores se confunde com a própria condição de homossexual. Parece que essas características se misturam no pensamento de ambos. Quando Estela se refere aos frequentadores como anormais, ela está se referindo ao comportamento deles ou a sua condição de homossexual que também não deixa de ser um tipo de comportamento? Será que seu incômodo, além de ser pelo comportamento 
em termos de educação, não acaba por se confundir e fundir com o incômodo com o próprio comportamento homossexual? Do mesmo modo, a fala de Marcelo sobre esse mau comportamento dos frequentadores, segue-se logo por uma reflexão sobre o que ele chama de homossexualismo. Até que ponto, Marcelo e Estela, de algum modo, não atribuem esse mau comportamento à condição de homossexual desses frequentadores, ou a um tipo de postura que, para eles, provém dessa posição? Mas, além desse confuso incômodo, é fato que existe algo no comportamento dos frequentadores que incomoda Marcelo e Estela e que não necessariamente está ligado à homossexualidade. Como sentar e colocar os pés na cadeira, cuspir no chão, colar chiclete debaixo das mesas e nas cadeiras e todas as coisas já citadas na fala de ambos.

Todos esses fatores fizeram com que o Beco, nos últimos anos, se tornasse um lugar extremamente estigmatizado e marginalizado. A grande maioria dos frequentadores, quando perguntei sobre o Beco, afirmaram que estavam ali por falta de opção, que o Beco já foi bom um dia, mas que hoje é um lugar muito vulgar e promíscuo. No entanto, esses mesmos frequentadores continuam a ir e a estabelecer algum tipo de identificação com o Beco dos Artistas. Wacquant (2004), em seu estudo sobre guetos, diz:

\footnotetext{
Essa identidade unificada acaba sendo marcada pela ambivalência, já que continua maculada pelo fato de a guetização proclamar o que Weber chama de avaliação negativa de honra do grupo confinado. Dessa maneira, ela promove em seus membros sentimentos de dúvida em relação a si mesmos, dissimulação de sua origem, desvalorização perniciosa de si mesmo. (WACQUANT, 2004: 160).
}

Guardando as devidas particularidades do objeto de pesquisa que é, com certeza, diferente do tipo de gueto que Wacquant (2004) estava se referindo, podemos, ainda assim, estabelecer algumas comparações. Entre elas, o fato de que muitos frequentadores do Beco, embora gostem de frequentá-lo e continuem frequentando, emitem uma opinião muito negativa do espaço. Muitos freqüentadores negam que freqüentam o Beco, pois frequentar o Beco é "queimação" no meio gay. Outros frequentadores afirmam que só vão para o Beco por falta de opção. Isso mostra o quanto a posição do frequentador do Beco dos Artistas, hoje, é uma posição ambivalente, no sentido de que, ao mesmo tempo em que existe uma identificação com o espaço e uma necessidade de vivê-lo, aproveitando a liberdade e as vantagens que esse espaço 
oferece, existe, também, uma interiorização da imagem negativa que é projetada no Beco. Uma conversa com dois rapazes que estavam no Beco elucida esse ponto:

\begin{abstract}
A - E o que vocês acham do Beco?
Y - Muito violento, muito sujo, gente baixo astral, só venho porque a sociedade não aceita a gente, a gente não tem outros lugares para ir, a gente tem que vir aqui para poder namorar e ficar com outras pessoas [...] não tem segurança, é um lugar perigoso aqui, vem gente fumar maconha, até assaltar, fica ali na porta do Beco, porque acha que todo gay é viadinho, é bichinha, é mulherzinha, é vulnerável, entendeu? E não é, tem muita gente que não é.

I - Apesar de tudo, eu me sinto bem aqui, eu me sinto a vontade para fazer o que eu quiser, a gente pode namorar.

Y- Acabou de ligar para mim agora um amigo meu e eu disse que estava em casa para não dizer que estava aqui, entendeu?
\end{abstract}

Essa conversa mostra a ambivalência presente na posição dos frequentadores. Essa posição ambivalente é extremamente recorrente. A maioria dos frequentadores sustenta uma opinião crítica em relação ao Beco, mas, continua frequentando-o. Muitas vezes, essa postura contribui para a reprodução do estigma que recai sobre o Beco. Ainda que essa postura se refira às condições materiais características do Beco, como o calçamento deteriorado, o lixo na porta do Beco, o uso de substâncias psicoativas, a falta de segurança, quando os entrevistados descrevem o comportamento dos frequentadores $^{8}$ do Beco, que eles próprios fazem parte, como promíscuo e vulgar, essa opinião pode ser fruto da internalização dos padrões de normalidade que vigoram Beco a fora, ou na sociedade mais ampla. O estigma não parte só das pessoas que estão fora do Beco, mas, dos próprios frequentadores. Goffman (1980) diz:

\begin{abstract}
$\mathrm{O}$ indivíduo estigmatizado tende a ter as mesmas crenças sobre identidade que a sociedade maior tem; isso é um fato central. Seus sentimentos mais profundos sobre o que ele é podem confundir a sua sensação de ser uma 'pessoa normal', um ser humano como qualquer outro, uma criatura, portanto, que merece um destino agradável e uma oportunidade legítima. (Goffman, 1980: 16)
\end{abstract}

Além dos frequentadores, as pessoas do bairro Garcia que conheceram o Beco desde seu início e outras pessoas de fora que conhecem o Beco, mas não são frequentadores, também sustentam a ideia que se cristaliza na dicotomia entre o Beco dos Artistas - esse Beco que um dia foi bom, divertido e saudável - e o Beco hoje como

\footnotetext{
${ }^{8}$ Muitos frequentadores inclusive não admitem que são frequentadores. Dizem que só vão ao Beco esporadicamente, que estão ali, mas, não gostam do lugar. Enfim, criam uma série de proposições que os tiram do lugar de pertencimento àquela atmosfera que eles consideram "baixo astral", o que permite que eles façam afirmações sobre o lugar e o público que o frequenta, sem, no entanto, se incluir nessas afirmações. Os frequentadores são sempre os outros e não aquele que enuncia.
} 
um lugar vulgar, promíscuo e sujo. Uma expressão que surge muito na fala das pessoas, quando se referem ao Beco, dos frequentadores e dos não frequentadores, é a "energia negativa”. Muitos afirmam que o Beco tem uma energia negativa, uma energia pesada e incômoda.

No entanto, essa energia negativa que as pessoas atribuem ao Beco não é uma áurea mística própria do lugar, mas está atrelada a questões sociais reais, como a cor da pele das pessoas que frequentam o Beco, as substâncias psicoativas, as formas como as pessoas se vestem, aos furtos, a classe social, aos comportamentos sexuais e as performances de gênero que são ali vivenciadas. O Beco concentra tipos de práticas, pessoas e comportamentos que são extremamente estigmatizados na nossa sociedade. E digo estigma aqui no sentido de Goffman (1980), como "características cujo efeito de descrédito é muito grande; algumas vezes consideradas defeitos, fraquezas ou desvantagens" (Goffman, 1980: 12). Um público majoritariamente jovem, de cor de pele negra, de camadas sociais menos favorecidas, de homossexuais e de alguns usuários de substâncias psicoativas. $\mathrm{O}$ viés de classe tem um peso forte para essa estigmatização do lugar. A fala de um antigo frequentador retrata bem esse viés:

A - Me fala mais um pouco da tua relação com Beco? O que te levava ao Beco? O que te leva hoje ao Beco?

L - Pé na jaca, quando eu quero enfiar o pé na jaca, eu vou ao Beco. Vamos abrir as portas da esperança. Tem uma amiga minha que diz assim: vamos para o zoológico! A gente vai para o BA que é um zoológico humano, eu vou lá por isso. Antigamente não, eu ia lá para ver peça, ouvir poesia. Ia porque minha namorada morava ali perto, a gente ia com esse climão mais cultural, hoje eu vou para pisar o pé na jaca. Vamos para baixaria? Mais para ver do que para participar. Ver bichinha pobre paquerando (grifo nosso), entendeu? Mas eu já tive momentos ruins no Beco. Gente cheirando pó no meio da rua, não pode acontecer isso. Mas há muito tempo eu não vou lá ao Beco. Quando eu quero alguma coisa mais misturada, eu vou lá ao Beco da Rosália.

Todo esse contexto e todos esses fatores já mencionados que contribuíram para a estigmatização do Beco, cristalizaram-se em uma sigla que os próprios frequentadores cunharam para o lugar, essa sigla é BA. Os frequentadores parodiaram o termo Beco dos Artistas e transformaram em BA, que significa Baixo Astral. Isso quer dizer que o Beco agora não é mais dos artistas como foi um dia, mas é, sim, um lugar Baixo Astral, o BA. Retira-se, então, toda a positividade do termo e enfatiza-se o aspecto negativo do Beco. Essa paródia do termo não possui um significado puramente semântico, mas, caracteriza mesmo a mudança de sentido que veio ocorrendo no Beco durante todos 
esses anos, ao mesmo tempo em que representa toda a carga negativa e o estigma que é projetado sobre o lugar e interiorizado por alguns frequentadores. A fala de Marcelo, responsável pelo Bar Cultural, marca bem essa passagem:

\begin{abstract}
Hoje, taxado como GLS, pela frequência que foi criada com o tempo. Hoje é taxado como GLS, mas deixou de ser Beco dos Artistas para ser chamado como BA. A maioria das pessoas conhece como BA e não como Beco dos Artistas. É a sigla do Beco dos Artistas, mas é uma forma de dizer que o Beco dos Artistas já deixou de ser de artistas, já faz muito tempo. Tanto que a maioria das pessoas que vem aqui, poucas delas fazem teatro, poucas delas fazem alguma coisa. Poucas delas têm uma função ou vocação na sociedade. São pessoas de nenhum nível, outras sem nenhum estudo, outras sem nenhuma cultura. Então, essas pessoas queimaram indiretamente o Beco, ou diretamente queimaram o Beco. E trouxe essa imagem feia para o Beco. Então, o Beco dos Artistas foi criado assim. Pessoas de famílias respeitosas vinham para cá ouvir som, voz e violão, tomar cerveja. Era um espaço aberto a todos os tipos de público. Quando é que começou a ser taxativo, começou a ser taxado como Beco dos viados, como Beco GLS. Que começou a chamar BA, Beco GLS, beco não sei o quê? Não se chamava mais Beco dos Artistas, usava-se a sigla porque se achava mais fácil. Como chamar de BA é chamar de "Baixo Astral". Começaram a queimar a imagem do Beco. Não porque se dizia que era um espaço gay, mas porque o público gay que começou a frequentar o espaço estava deixando uma imagem feia, mal vista para a sociedade. Como se agarrar na porta da entrada do Beco, como fazer sexo no fundo do Beco, como fumar maconha na entrada, no meio e no final do Beco, como cheirar pó dentro do estabelecimento e até na entrada do Beco.
\end{abstract}

É notório, pela fala de Marcelo, como essa nova sigla, BA, está relacionada ao fato de o Beco ter-se tornado, ao longo desses anos, um espaço de sociabilidade GLS ou "o beco dos viados". O título de "Baixo Astral" não se resume a isso, mas é fato que hoje a principal característica do Beco, antes de ser um lugar onde existe o uso de drogas, um público de baixo poder aquisitivo e de cor de pele negra, é o fato de ele ser um beco de sociabilidade GLS. Assim, a mudança em termos semânticos de Beco dos Artistas para "Baixo Astral" corresponde à mudança na realidade empírica, de um lugar frequentado por artistas e intelectuais para um lugar de sociabilidade especificamente GLS - um reduto de gay, negro e pobre.

Essa visão negativa do Beco contrasta, no entanto, com um espaço que é frequentado de terça-feira a domingo, dias com mais gente, dias com menos gente. Um lugar que ainda exerce uma atração sobre as pessoas. Nas sextas-feiras e sábados o Beco fervilha de gente, os bares e a rua ficam cheios. O Beco traz essa ambivalência de sentido, ao mesmo tempo em que é muito estigmatizado, é um lugar que continua a atrair as pessoas e não só das camadas mais desfavorecidas, embora estas estejam lá em maioria, atrai pessoas também de classe média, intelectuais que, ainda hoje, frequentam o lugar. Pessoas que vêem no Beco uma possibilidade de diversão, de alegria. É, nesse 
sentido, um lugar que cumpre um papel, que tem uma função. Ainda é um espaço de sociabilidade que permite os encontros e as trocas.

\section{Considerações finais}

O Beco dos Artistas se apresentou, ao longo do artigo, como um lugar extremamente rico para pensar sobre diferentes posições de gênero e desejo, para pensar sobre a relação que existe entre diferentes posições marginais e, nesse sentido, a interseccionalidade entre raça, classe, gênero e sexualidade. Além disso, o Beco, como esse lugar acolhedor de práticas marginais, nos possibilita pensar sobre a categoria do estigma e sobre a internalização do estigma por parte dos próprios frequentadores do lugar. Essa estigmatização marcou o lugar ao ponto de este deixar de ser considerado, pelos seus frequentadores, o Beco dos Artistas para se tornar o BA, quer dizer, um lugar Baixo Astral.

O texto nos mostra que diferentes posições de gênero eram assumidas pelos frequentadores do Beco. Existiam gays mais afeminados, gays mais masculinos, lésbicas mais femininas, lésbicas mais masculinas, assim como pessoas que manejavam ora os atributos de feminilidade ora os atributos de masculinidade. Essas posições de gênero não guardavam uma relação direta com a sexualidade dos indivíduos ou com suas preferências em termos de desejo. Nem sempre os pares formados por esses sujeitos correspondiam ao padrão heterossexual de um polo masculino e outro feminino ou a díade de passividade e atividade. Essa situação mostra que, primeiro, nem sempre as relações homossexuais reproduzem os estereótipos heterossexuais presentes na sociedade mais ampla e, segundo, a relação que se estabelece entre gênero e sexualidade nem sempre se dá de uma forma direta e determinista a partir da definição do sexo biológico (Butler, 2008). Pode-se atentar, também, para o fato de que a transgressão desses padrões de sexualidade e gênero Beco à dentro contribui para questionar a lógica heteronormativa que pressupõe uma coerência entre sexo/gênero/desejo e prática sexual na experiência dos indivíduos.

O texto também nos mostra como posições marginais tendem a se concentrar no espaço. Práticas como o furto, o uso de substâncias psicoativas, a prostituição masculina, a publicização do sexo se concentram no lugar/Beco, mais especificamente no espaço da rua. Wacquant (2004) e Perlongher (1987) já chamavam a atenção para a 
proximidade dessas práticas em termos de posições marginais. Todas essas práticas transgridem normas socialmente aceitas e que, supostamente, resguardam a "ordem social". Dessa maneira, essas práticas tendem a ser rechaçadas socialmente e colocadas em posições marginais diante dos padrões de convivência social mais hegemônicos. Daí que essa marginalização tende também a reverberar no espaço, criando o que Perlongher (1987) chama de territorialidades marginais. O Beco e, principalmente, o espaço da rua, tende a concentrar em seu interior tais práticas. Ao que tudo indica, essa concentração de práticas marginais se deve ao fato de que o principal marcador, atualmente, do Beco, seja a sua identidade homossexual - uma identidade ainda maculada socialmente, ainda alvo de um descrédito social.

A parte isso, o Beco também concentra, em seu interior, jovens cuja maioria provém das periferias de Salvador, de baixo poder aquisitivo, negros e homossexuais. A conjunção desses fatores leva a uma profunda estigmatização do lugar, inclusive, dentro do meio homossexual. É muito comum que os jovens negros vindos da periferia, tanto homens quanto mulheres, apresentem uma tendência maior a manejar atributos de gênero distintos do seu sexo biológico - mulheres masculinas e homens afeminados. Talvez isso aconteça, como bem coloca Facchini (2009), porque as pressões em termos de adequação do gênero ao sexo biológico variem segundo a classe social do indivíduo. Em geral, os gays e lésbicas de classe média que frequentavam o Beco apresentavam uma preocupação maior em corresponder as normas de gênero que lhes eram impostas. A conjunção do fator de classe (pobres) e de raça (negros) com o fator de gênero (dissonância entre o comportamento de gênero e o sexo biológico desses sujeitos) e a sexualidade (o desejo entre pessoas do mesmo sexo) fez com que o Beco dos Artistas se tornasse um alvo de profunda estigmatização.

O estigma, para Goffman (1980), consiste em características sob as quais recai um efeito de descrédito muito grande ou, como para Wacquant (2204), consiste na avaliação negativa de um grupo. Nota-se que o estigma, que marca o Beco e seus frequentadores, é uma consequência dos fatores de classe, raça, mas, sobretudo, dos comportamentos referentes ao gênero e a sexualidade. O Beco dos Artistas é, primeiramente, conhecido como beco dos viados, as outras características são derivadas como, por exemplo, o beco de bicha pobre ou de bicha betume ${ }^{9}$. O estigma, no entanto, não é uma força que age só de fora para dentro; o estigma se movimenta, vai e volta.

\footnotetext{
${ }^{9}$ Betume é um liquido de cor escura que se origina do petróleo. $\mathrm{O}$ adjetivo se refere à cor de pele negra dos frequentadores do Beco.
} 
Assim, esse descrédito, essa avaliação negativa do lugar é internalizada e, consequentemente, reproduzida pelos próprios frequentadores. Esse movimento do estigma é perceptível quando os frequentadores assumem, para si, uma visão negativa do seu comportamento e, por conseguinte, do lugar e, nesse fluxo, retroalimentam essa estigmatização.

Não é à toa que muitos frequentadores não assumem em outros ambientes que frequentam o Beco e que apesar de frequentá-lo de terça a domingo continuam atribuindo ao lugar características negativas. Seguindo essa lógica, os frequentadores cunharam o termo BA, que quer dizer Baixo Astral, para classificar semanticamente o sentimento de negatividade e descrédito que se materializa no lugar, mas também, nas suas próprias subjetividades. Quando o Beco é nomeado pelo rótulo BA ele perde todo o sentido positivo que estava atrelado ao termo Beco dos Artistas e assume semanticamente o sentimento de negatividade e estigmatização que já vinha se materializando no lugar e nas subjetividades dos frequentadores. Torna-se evidente, portanto, que a materialização desse sentido na linguagem é fruto do forte estigma que recaiu sobre um lugar que concentra, em seu interior, indivíduos marcados pela intersecção de fatores como cor de pele negra, baixo poder de consumo e, sobretudo, prática homossexual.

\section{Referências}

BUTLER, Judith. O parentesco é sempre tido como heterossexual? Cadernos Pagu, Unicamp, n. 21, 2003, p.219-260.

Problemas de Gênero. Rio de Janeiro: Civilização Brasileira, 2008.

Criticamente Subversiva. In: JIMÉNEZ, Rafael M. Mérida. Sexualidades transgresoras. Una antología de estudios queer. Barcelona: Icária editorial, 2002, p. 55 a 81.

FACCHINI, Regina. Entrecruzando diferenças: mulheres e (homo)sexualidades na cidade de São Paulo. In: Díaz-Benítez, Maria Elvira; Fígari, Carlos Eduardo (orgs.). Prazeres Dissidentes. Rio de Janeiro: Garamond, 2009, p. 309-342.

FOUCAULT, Michel. História da sexualidade I - a vontade de saber. Rio de janeiro: Graal, 2007.

Não ao sexo rei. In: FOUCAULT, Michel. Microfísica do poder. Rio de Janeiro: Graal, 1985, p. 229-242. 
Sobre a história da sexualidade. In: FOUCAULT, Michel. Microfísica do poder. Rio de Janeiro: Graal, 1985, p. 243-276.

FRANÇA, Isadora Lins. Sobre "guetos" e "rótulos": tensões no mercado GLS na cidade de São Paulo. Cad. Pagu, Campinas, n.28, jun. 2007. Disponível em <http://www.scielo.br/scielo.php?script=sci_arttext\&pid=S010483332007000100011\&I ng=pt\&nrm=iso $>$ acessos em 02 de maio 2011.doi:10.1590/S0104-83332007000100011. FRY, Peter. Para Inglês Ver: identidade e política na cultura brasileira. Rio de Janeiro: Zahar, 1982.

GOFFMAN, Erving. Estigma: notas sobre a manipulação da identidade deteriorada. Tradução de Márcia Bandeira de Mello Leite Nunes. $3^{\text {a }}$ ed. Rio de Janeiro, Zahar, 1980.

LACOMBE, Andrea. "Tu é ruim de transa!" Ou como etnografar contextos de sedução lésbica em duas boates GLBT do subúrbio do Rio de Janeiro. In: Díaz-Benítez, Maria Elvira; Fígari, Carlos Eduardo (orgs.). Prazeres Dissidentes. Rio de Janeiro: Garamond, 2009, p.373-392.

LOURO, Guacira Lopes. Um corpo estranho: ensaios sobre a sexualidade e teoria queer. Belo Horizonte: Autêntica, 2004.

LOYOLA, Maria Andréa. Sexo e sexualidades na antropologia. In: LOYOLA, Maria Andréa (org.). A sexualidade nas ciências humanas. Rio de Janeiro: EdUERJ, 1998, p. 17-47.

PERLONGHER, Nestor. O negócio do michê: prostituição viril em São Paulo. São Paulo: Editora. Brasiliense, 1987.

SIMMEL, Jorge. El Espacio y La Sociedad. In: Sociología: estúdios sobre las formas de socialización. Tracucción del Aleman por J. Pérez Bances. Buenos Aires: Espasa-Calpe, 1939, cap IX, p. 207-288.

SIMÕES, Júlio Assis. Sexualidade, gênero, raça e idade em circuitos de sociabilidade homoerótica em São Paulo. In: 26a. Reunião Brasileira de Antropologia, 2008, Porto Seguro. 26a. Reunião Brasileira de Antropologia, 2008.

SIMÕES, Júlio Assis e FRANÇA, Isadora Lins. Do Gueto ao mercado. In: GREEN, James Naylor; TRINDADE, Ronaldo. (orgs.) Homossexualismo em São Paulo e outros escritos. São Paulo, Editora Unesp, 2005.

WACQUANT, Loïc. Que é gueto? Construindo um conceito sociológico. Rev. Sociol. Polit. [Online] 2004, n.23 [cited 2010-01-17], pp. 155-164. Available from: $<$ http://www.scielo.br/scielo.php?script=sci_arttext\&pid=S010444782004000200014\&lng=en\& nrm=iso>. ISSN 0104-4478. doi: 10.1590/S0104-44782004000200014.

Recebido em: 30/09/2014 Aprovado em: 06/11/2014 